\title{
The Role of Extracellular Matrix Quality in Pulmonary Fibrosis
}

\author{
Jacob Hull Kristensen ${ }^{a, b}$ Morten Asser Karsdal ${ }^{a}$ Federica Genovese $^{a}$ \\ Simon Johnson ${ }^{c}$ Birte Svensson ${ }^{b}$ Susanne Jacobsen ${ }^{b}$ Per Hägglund ${ }^{b}$ \\ Diana Julie Leeming ${ }^{\text {a }}$ \\ ${ }^{a}$ Nordic Bioscience, Herlev, and b ${ }^{b}$ Department of Systems Biology, Technical University of Denmark, Lyngby, \\ Denmark; ' ${ }^{C}$ School of Clinical Sciences Nottingham, The University of Nottingham, Nottingham, UK
}

\section{Key Words \\ Chronic lung disease - Extracellular matrix · Fibrosis . \\ Idiopathic pulmonary fibrosis · Lung biochemistry . \\ Protein biomarkers · Protein function · Protein structure}

We discuss and argue that the altered quality of the individual ECM proteins contributes to the progression of PF and may also lead to the increased quantity of lung proteins. Thus, both quantity and quality appear to be of utmost importance.

(c) 2014 S. Karger AG, Basel

\begin{abstract}
This review discusses the role of extracellular matrix (ECM) quality in the pathogenesis of pulmonary fibrosis (PF). In PF, the highly ordered structure of collagens and elastin within the ECM of the lung is severely disrupted and lacks its original tissue quality. Discussions about the ECM have focused on the role of protein quantity in relation to the progression of $P F$, while the importance of lung ECM quality, defined by the levels of ECM protein modifications and by the protein distribution in lung tissue, has not been properly addressed. The quality and function of proteins may be altered by different post-translational modifications (PTMs), such as crosslinking, proteolytic cleavage, citrullination, misfolding and glycosylation. This paper is the first to review key data from the literature related to the lung ECM at the molecular level, relate these to changes observed at a macroscopic level and evaluate which PTMs most likely contribute to PF. This paper also reviews the role of novel neo-epitope-specific biomarkers in the early diagnosis and prognosis of fibrotic disorders.
\end{abstract}

\section{Introduction}

Substantial changes in the normal distribution of various extracellular matrix (ECM) proteins are observed in a number of diseases [1]. The function of the ECM was originally thought to be exclusively structural, but it is now commonly acknowledged that its role stretches beyond structural changes and may include regulatory properties [1]. There are several indications that even a few changes in the complex distribution of ECM proteins can trigger severe damage of tissue [2-9]. In addition to changes in their distribution, proteins in the ECM may also be altered on a quantitative scale and at the molecular level, involving modifications to their chemical structure or to their natural degradation and rebuilding process. Examples of potential relationships between abnormal ECM protein structures or processes and tissue

\section{KARGER}

E-Mail karger@karger.com www.karger.com/res
C 2014 S. Karger AG, Basel

0025-7931/14/0886-0487\$39.50/0
Jacob Hull Kristensen, MSc

Department of Biomarkers and Research Nordic Bioscience, Herlev Hovedgade 207 DK-2730 Herlev (Denmark)

E-Mail jhk@nordicbioscience.com 
damage are the elevated levels of collagen cross-linking enzymes seen in pulmonary fibrosis (PF) [2] and the increased proteolytic cleavage and cross-linking of elastin $[10,11]$.

In this review, we focus mainly on the function, quantity and distribution of collagens and elastin, which constitute the majority of ECM proteins in lung tissue [1214], during the progression of PF. The lung ECM has not been investigated to the same extent as the ECM in other tissues such as bone and cartilage [1], and some lessons may be learned from those studies. PF occurs during the progression of idiopathic PF (IPF) [15], which is a lung disorder with one of the highest mortality rates. ECM quality and quantity in lung disorders with a focus on IPF will be discussed, along with the most important posttranslational modifications (PTMs) of proteins in the lung ECM (mainly cross-linking and proteolysis) and the processes leading to IPF.

\section{Idiopathic PF}

IPF is the most common idiopathic interstitial pneumonia and has one of the worst prognoses of all pulmonary diseases $[16,17]$. Patients with IPF have a median survival of 2.5-3.5 years after diagnosis [16, 18]. Even in aggressive cancer types, except for lung and pancreatic cancer, the survival rates after diagnosis are higher than for IPF [15]. IPF was earlier considered a progressive inflammatory related disease in which fibroblast proliferation and extracellular remodelling leads to scar formation or fibrosis of the lungs [15]. This theory has now been replaced with the chronic epithelial lesion paradigm that posits that there is a continuous damage to the epithelium together with insufficient repair and hyperplasia. This is followed by an epithelial-mesenchymal transition during which epithelial cells undergo a transition to a mesenchymal phenotype leading to fibroblast and myofibroblast phenotypes [19]. This may initiate the deposition of excessive amounts of ECM material in the lungs. Several growth factors may have active roles in the initiation of PF. These include, among others: TGF- $\beta$ [20], CTGF [21], ET-1 [22], TNF- $\alpha$ [23], PDGF [24] and Wnt [25]. A wider description of their role is not included here as the focus is on lung ECM proteins. The specific process responsible for the failure in epithelial repair that leads to excessive deposition of ECM proteins remains unknown.

The main clinical challenges for IPF is that the disease is diagnosed relatively late, and there are currently no prognostic markers or even simple serological markers that can be used to identify patients who are fast progressors and thus in most need of intervention. Therefore, more focus directed towards the progression of IPF is needed.

\section{ECM of the Lung}

The ECM is a 3-dimensional network that maintains the structure of tissues and organs by encapsulating cells and defining their microenvironment [9]. It consists of a highly organized, complex network of arranged proteins. Soluble factors such as cytokines and growth factors may adhere to the network and cells may migrate into it. Previously the ECM was thought to only maintain structural properties, but its role in various diseases has been reviewed [1] and it is now also considered a central regulator of cell and tissue behaviour via transmembrane signalling $[26,27]$. In this section, we list some of the main structural properties of the ECM.

Two types of structural ECM exist: (1) the basement membrane interacts with the epithelium and endothelium and consists mainly of type IV collagen, laminin, entactin/nidogen and heparin sulphate proteoglycans [28]; (2) the interstitial matrix constitutes the bulk of the ECM. Elastin and several types of collagens contribute, together with fibronectin, to the mechanical strength of the tissue [26].

While the basic composition and characteristics of the basement membrane and interstitial matrix are similar in different tissues, the variations in ECM components, for example in the expression of protein isoforms, PTMs and the ratio between individual matrix proteins, contribute to the differentiation of ECM organization and structure throughout the body. This ensures tissue specificity [2931].

The lung ECM includes several structural proteins. These are mainly collagens, elastin, proteoglycans, fibronectin and laminin.

Several studies have linked the levels of lung ECM protein fragments of, for example, elastin and collagen type I, III, IV, V and VI to lung disorders such as chronic obstructive pulmonary disease (COPD) and IPF [32-35].

The collagen superfamily contains at least 27 collagen types and accounts for approximately $20 \%$ of the dry weight of the lung ECM [14]. Cross-linking is the final step in the biosynthesis of collagen and it is essential for the physical and mechanical properties of collagen fibrils. Cross-linking is an enzymatic process that is performed 
mainly by the enzymes lysyl oxidase (LOX) and transglutaminase (TG) [36-40]. The large number of cross-links contributes to the characteristically high tensile strength and minimal extensibility of collagens.

Elastin provides elasticity and resilience to many tissues and organs including the lung, skin, aorta, ligaments, tendons and cartilage and is therefore considered critical for their long-term functions [41]. The precursor of elastin, known as tropoelastin, is secreted from fibroblasts, smooth muscle cells, chondrocytes or endothelial cells before it is degraded to elastin [42]. The formation of covalent lysyl-derived desmosine cross-links by LOX further stabilizes the formed elastin fibres [43]. Elastic fibres are designed to maintain their elastic function for a lifetime and, once formed, are mostly only degraded by a few specialized proteases. Elastin is mainly degraded by matrix metalloproteinases (MMPs) and serine and cysteine proteases including neutrophil elastase (NE) [4, 44-47]. It accounts for more than $30 \%$ of the dry weight of the lung $[12,13]$ and is therefore the most representative protein of the lung ECM. Elastin is predominant in the pleura, alveolar septa and walls of the blood vessels and airways covering the thin, highly branched respiratory tree. Its ability to extend and contract enables alveolar expansion and recoil during breathing [48].

Hyaluronic acid (HA) is a non-sulphated glycosaminoglycan. Li et al. [49] demonstrated how overexpression of HA synthase 2 (HAS2) could induce PF. Deletion of HAS2 also inhibited the development of PF. HA may therefore contribute to the initiation of PF.

Integrins are essential for ECM remodelling as they transduce signals from the interior of the cells to the ECM and vice versa. Integrin regulation of TGF- $\beta$ can lead to several fibrotic diseases including IPF [50].

Other molecules comprising the lung ECM may include fibrinogen, which is a glycoprotein. Laminin is the most abundant glycoprotein in the lung ECM basement membrane and is often associated with entactin [5]. Proteoglycans are also found in the integral membrane of lung cells or the lung ECM [5].

\section{PTMs in the Lung ECM}

PTMs are modifications of proteins that are non-DNA coded but are a consequence of the physiological or pathological state of a cell/tissue. PTMs of proteins are also known as neo-epitopes [31]. PTMs expand the chemical opportunities of a protein further than is possible with the 20 amino acid monomers alone. PTMs also enable regu- lation of a protein in its current state and location and provide the opportunity to monitor the state of a cell or tissue as PTM-specific biomarkers have proven previously [30]. They are often embedded in the non-globular regions of a protein $[51,52]$. The focus is directed here towards the PTMs relevant for the organization of the ECM, mainly proteolytic cleavage and cross-linking. We will present examples from different diseases arising from ECM disorders and discuss PTMs that are of importance in lung disorders/fibrosis, especially IPF. A more extensive description of all of the PTMs observed in various diseases has been presented previously [29, 30]. Some PTMs discussed here have previously been identified and utilized as biomarkers for measuring pathological activity $[31,53]$. This includes proteolytic cleavage, citrullination, cross-linking and glycosylation. The lung requires a large airway and epithelial surface area to function optimally, and this area is therefore constantly exposed to external factors that could affect the regulation of PTMs towards proteins of the lung ECM.

\section{Glycosylation}

Glycosylation is a common PTM. A well-known example of how glycosylation has been applied in diagnostics is the glycosylation of haemoglobin $\mathrm{A}_{12}$ [54] used to evaluate diabetes [55]. This example shows how a diseasespecific PTM may enable a more precise diagnosis than measurements on intact molecules. Hyperglycosylation is also present in pulmonary diseases such as chronic bronchitis and cystic fibrosis, where it affects the airway's innate immunity and promotes the attachment of pathogens $[56,57]$.

\section{Proteolytic Cleavage}

Among the most pathologically relevant PTMs in the lung are proteolytic cleavage of collagen and elastin by MMPs [8, 34, 36, 44, 46, 58-62] and NE [61, 63, 64]. The role of this modification in lung diseases was examined by analysing how MMP-induced elastin and collagen neo-epitopes are related to lung tissue degradation [33, 34]. This can be coupled to the properties of matrikines. Matrikines are ECM protein fragments that can regulate cell activity, which has been demonstrated by the antielastin autoimmunity induced by elastin matrikines in emphysema $[65,66]$. The fragments were able to stimulate an immune response in tissues, with upregulation of cytokines leading to an increase in protease expression, which results in progressive destruction of the lung ECM [66]. Proteolytic cleavages may therefore have structural as well as regulative purposes in the lung ECM. 


\section{Cross-Linking}

Cross-linking strongly affects the mechanical properties of the ECM, such as viscoelasticity and stiffness, which may enhance the mechanical strength of the tissue [67]. This is relevant as both the stiffness and the topology of the ECM regulate the growth, remodelling, differentiation, migration and phenotypes of a wide variety of cells and tissues [68-70].

LOX is a Cu-proenzyme that is essential for the stabilization of the lung ECM, inducing cross-linking of elastin and collagens in particular. The formation of these lysine-derived cross-links in connective tissue may constitute an essential defence against the proteolysis of elastin and collagen performed by non-specific proteases. LOX has the highest affinity for collagens precipitated in the form of fibrils and for clustered forms of elastin [71]. The number of cross-links per collagen molecule has been shown to be elevated in fibrotic tissue compared to the healthy state [72]. LOX has been pointed out as a main contributor to the increase in cross-linking in several diseases including PF [73]. This was demonstrated by a dramatic increase in LOX activity during the development of $\mathrm{PF}$ [73]. The distribution of LOX is tissue specific [74, 75]. LOX levels may also have an effect on the expression levels of ECM proteins such as elastin, where an increase in LOX induces an increase in elastin synthesis [76]. The LOX family consists of 9 members, among which LOXlike-2 (LOXL2) is the most expressed [38]. LOXL2 has been found to be over-expressed in lung tissue samples from IPF patients, especially in tissues with activated fibroblasts, reactive pneumocytes and vasculature in fibroblast foci [77].

Another ECM cross-linking enzyme is TG, which catalyses $\mathrm{Ca}^{2+}$-dependent acyl-transfer reactions between the $\gamma$-carboxamide group of specific glutamine residues and primary amines (e.g. the $\varepsilon$-amino group of lysine residues). This results in the formation of an $\mathrm{N}^{\varepsilon}(\gamma$-glutamyl) lysine cross-link [78]. The TG family includes 8 catalytic TG and 1 non-catalytic relative that lack TG activity [79]. The members of the TG family differ in tissue expression and function, and TG2 in particular has received increasing attention among fibrotic disorders. TG2, also known as tissueTG or tTG, is vital for the maturation of the lung ECM [80] and plays a role in the development of PF [39, 81].

\section{Oxidation}

Considering the high diffusion of oxygen gases and oxygen tension in the lung, oxidation of ECM proteins is an important PTM in pulmonary disorders. Thus, reac- tive oxygen species (ROS) may play a role in the progression of PF. This is demonstrated by the correlation of ROS levels with low pulmonary function in IPF patients and low ROS levels in controls [82]. These oxidative compounds may disturb the fine balance between oxidants and anti-oxidants in the lungs. It is the leucocytes that are responsible for the oxidase production in the lungs [83]. The high presence of oxidizing compounds in the lungs of IPF patients may not solely originate from smoking as oxidized proteins levels (new carbonyl groups) are also increased in the lungs of non-smoking IPF patients [84]. A temporary increase in anti-oxidant synthesis has been observed in bronchoalveolar lavage fluid from IPF patients as a means of compensation for the high oxidative stress [85]. However, local decreases in anti-oxidants have still been reported in fibrotic regions of the human lung, suggesting a predominance of oxidants in fibrotic regions [86]. Furthermore, the regulation of MMPs and their inhibitors may be changed by oxidative groups affecting lung ECM remodelling [87], and the apoptosis of cells may be enhanced by oxidative modifications of the Fas receptor [88].

\section{Citrullination}

A relevant PTM is the citrullination of arginine into citrulline. Arginine deamination removes its positive charge at a neutral $\mathrm{pH}$, altering the isoelectric point of a protein $[89,90]$. This results in a more open structure, which makes proteins more vulnerable to proteolysis [91] or may affect cell signalling of the proteins [92, 93]. Citrullinated proteins have also been found to have a less organized structure and to be a more favourable substrate for TG [94]. Citrullination has been previously linked to fibrosis as studies have shown an increase in citrullinated protein in liver fibrosis [95].

\section{Protein (Mis)Folding}

PTMs can be more complex than the examples of modifications discussed above. Especially the mechanisms leading to proper protein folding may be disturbed in the disordered distribution of ECM proteins during the progression of lung pathologies. The proteostasis network has been defined as a complex system that includes chaperones, protein disulphide isomerases, degradation components and multiple signalling networks that control both the composition and the concentration of its components in response to the cellular genome and the local environment to maintain proteome health/quality [96]. Disturbances in the proteostatic processes can induce a loss of protein function and/or aggregation of the 
Table 1. PTMs of proteins and their consequences

\begin{tabular}{|c|c|c|c|c|c|c|}
\hline PTMs & Enzymes & Protein targets & Original PTM functions & Tissues & $\begin{array}{l}\text { Biological consequences of } \\
\text { uncontrolled PTMs }\end{array}$ & References \\
\hline \multirow[t]{3}{*}{$\begin{array}{l}\text { Proteolytic } \\
\text { cleavage }\end{array}$} & NE, MMPs & Elastin & ECM remodelling & Lung & $\begin{array}{l}\text { Parenchymal destruction, } \\
\text { fibrosis }\end{array}$ & $\begin{array}{l}4,8,34,44 \\
60,128\end{array}$ \\
\hline & MMPs & Collagen & ECM remodelling & Lung & $\begin{array}{l}\text { Increased parenchymal cell } \\
\text { death }\end{array}$ & $8,58,129$ \\
\hline & MMPs & Vimentin & ECM remodelling & Liver & Fibrosis & 95 \\
\hline Oxidation & & Fas receptor & & Lung & Enhanced apoptosis of cells & 88 \\
\hline Cross-linking & TG & Collagen & Assembly/stability of the ECM & Lung, liver & Fibrosis & 39,40 \\
\hline Glycosylation & $\begin{array}{l}\text { Glycosyl- } \\
\text { transferase }\end{array}$ & Mucin & $\begin{array}{l}\text { Folding, stability, secretion of } \\
\text { proteins }\end{array}$ & Lung & Fibrosis, chronic bronchitis & $\begin{array}{l}56,57,131, \\
132\end{array}$ \\
\hline
\end{tabular}

PAD = Peptidylarginine deiminase

misfolded proteins [97]. This also occurs in pulmonary diseases where proteostasis may play a significant role [96]. Furthermore, recommendations from the National Heart, Lung and Blood Institute include a greater focus on the improvement of biomarkers directed against the proteostatic changes in pulmonary diseases [98].

Table 1 lists some of the consequences of uncontrolled proteolytic cleavage, oxidation, citrullination, cross-linking and glycosylation. These include, among others, fibrosis and various pulmonary disorders. These examples emphasize how PTMs may play a significant role in the progression of fibrotic diseases, particularly in the lung.

\section{Biochemical Markers in the Diagnosis and Prognosis of Lung Diseases}

As a consequence of ECM remodelling, protease-derived fragments of proteins are deposited locally in pathologically affected tissues and released into the blood/urine where they may be detected as serological biochemical markers [1]. Several novel specific biomarkers have been developed for the detection of such neo-epitopes and have proven successful for the assessment of fibrotic diseases [31-34, 53, 99-101]. Table 2 includes novel serological biomarkers that are relevant in fibrosis, including a broad range of biomarkers assessing certain ECM protein fragments that originate after specific PTM processing. These biomarkers are often unaffected by the total amount of proteins (quantity) but are very specific towards neo-epitopes elevated in fibrotic diseases [33]. Biomarkers specific for MMP-derived collagen fragments have been shown to have diagnostic value in COPD and IPF patients and are able to distinguish between two diseases with low and high levels of fibrosis, respectively [33]. In other studies, biomarkers specific for elastin fragments were able to quantify elastin fragments in serum of COPD and IPF patients and showed that the level of MMP-degraded fragments of elastin was raised in diseased patients compared to controls $[33,34]$. This illustrates how MMP-derived fragments of ECM proteins are relevant in pulmonary disorders/fibrosis.

\section{Protein Quantity in the Progression of PF}

\section{Protease/Protease Inhibitor Imbalance}

The precise event that causes the onset of PF is still not fully understood. The focus has generally been directed towards quantification of proteins such as elastin and collagens or cells such as neutrophils and macrophages which are known to be important for the lung milieu [1, 
Table 2. Selected state-of-the-art serological biomarkers assessing the quantity and degradation of proteins

\begin{tabular}{|c|c|c|c|}
\hline Biomarker & Protein & $\begin{array}{l}\text { Disease with altered } \\
\text { concentrations }\end{array}$ & References \\
\hline \multicolumn{4}{|c|}{ Intact protein biomarker } \\
\hline MMP-7 & MMP-7 & IPF & 127,133 \\
\hline Biomarkers & ECM processes & $\begin{array}{l}\text { Diseases with altered } \\
\text { neo-epitope } \\
\text { concentrations }\end{array}$ & References \\
\hline \multicolumn{4}{|c|}{ Partial protein biomarkers } \\
\hline $\mathrm{C} 1 \mathrm{M}$ & MMP-mediated type I collagen degradation & Liver fibrosis & 134 \\
\hline $\mathrm{C} 3 \mathrm{M}$ & MMP-mediated type III collagen degradation & IPF, COPD & 135 \\
\hline $\mathrm{C} 4 \mathrm{M}$ & MMP-mediated type IV collagen degradation & COPD & 35 \\
\hline $\mathrm{C} 5 \mathrm{M}$ & MMP-mediated type V collagen degradation & IPF, COPD & 136 \\
\hline C6M & MMP-mediated type VI collagen degradation & IPF, COPD & 137 \\
\hline P1NP & Type I collagen formation in tissues other than bone & Liver fibrosis & 138 \\
\hline P4NP 7S & Type IV collagen formation & Liver fibrosis & 139 \\
\hline $\mathrm{P} 5 \mathrm{CP}$ & Type V collagen formation & Liver fibrosis & 140 \\
\hline PIIINP & Type III collagen formation & Liver fibrosis & 141 \\
\hline VICM & MMP-mediated citrullinated vimentin degradation & Liver fibrosis & 95 \\
\hline ELM & MMP-mediated elastin degradation & IPF, COPD & 142 \\
\hline BGM & MMP-mediated biglycan degradation & Liver fibrosis & 143 \\
\hline HA & Hyaluronic acid & Liver fibrosis & 141 \\
\hline $\mathrm{MCV}$ & Mutated citrullinated vimentin & Rheumatoid arthritis & 144 \\
\hline
\end{tabular}

$33,64,102]$. The quantity of structural proteins is important in the pathology of PF; however, the amounts of proteases and protease inhibitors are just as relevant [64, 103]. Localized degradation of structural proteins in the lung ECM is often coupled with a confined increase in protease activity [1]. Within healthy lungs, there is a balance between ECM formation and degradation in order to obtain proper tissue remodelling. This tissue balance is not limited to a steady production of ECM proteins. A fragile balance between ECM-degrading enzymes and their inhibitors exists in the human lung [64]. A disturbance in the protease-anti-protease ratio may be induced by external factors such as smoking. Some studies indicate that this imbalance may progress into lung disorders such COPD or IPF if the balance tips towards the proteases or the anti-proteases, respectively [64, 104-106].

\section{Angiogenesis}

The role of protease/protease inhibitor imbalance as the main initiator of IPF is, however, considered outdated. The protease/protease inhibitor discussion has been replaced with other theories including the role of the imbalance in the angiogenic/angiostatic ratio. Angiogenic growth factors in the lung may upregulate the expression of ECM components and thus disturb ECM remodelling [107]. The role of angiogenesis in the progression of IPF has been reviewed in recent years [108]. It has, however, not been confirmed whether an increase or a decrease in angiogenesis initiates IPF.

\section{Protein Quality in the Progression of PF}

Although many studies have indicated that the progression of $\mathrm{PF}$ is initiated primarily by a change in the quantity of ECM proteins and cells in the lung, so far no conclusive evidence has been provided of whether it is the quantity or the quality of the proteins, or both, that is responsible for the progression of PF. The quality of ECM proteins may be defined by the levels of modifications such as proteolytic cleavage, cross-linking and their distribution in lung tissue.

To obtain a deeper insight into the progression of $\mathrm{PF}$, it is useful to focus not only on quantitative/visual observations (such as fibroblast foci and cell and protein quantities) but also on factors at the molecular level, including analysis of PTMs, which may cause only minor chemical changes but can also contribute to the progression of PF. 


\section{ECM Quality in Non-Lung Tissues}

Few studies have focused on the role of the ECM quality during lung disease progression. Nevertheless, the effects of changes in ECM quality have been explored in other diseases such as osteoporosis, where the ECM of the bones is changed in terms of both quantity and quality [109-111]. In osteoporosis, the effect of non-enzymatic cross-linking of collagen on bone toughness and ECM quality in particular has been investigated [110]. It is known that many cancer types metastasize to bone [112]. When the bone microenvironment is invaded by cancer cells, the secretion of ECM proteins with specific neoepitopes increases. These changes have been utilized for the development of a biochemical marker to detect locally high bone turnover by osteoclasts [101].

\section{Anti-Oxidants May Stop the Progression of Fibrosis}

Knowledge of oxidative reactants as markers for PF has been valuable in various clinical studies that have included anti-oxidants as a possible drug in PF treatment. Different anti-oxidants have been administrated to bleomycin- and asbestos-treated mice, followed by a reduction in PF. This includes anti-oxidants such as catalase [113] and carnosine [114]. In humans, administration of the anti-oxidant glutathione has resulted in a higher anti-oxidant-to-oxidant ratio in the lungs [115]. As an example of the importance of anti-oxidants in PF, even the known anti-fibrotic agent pirfenidone possesses some anti-oxidative effects [116]. The administration of anti-oxidants together with other known anti-fibrotic compounds has shown that anti-oxidants may enhance the effect of anti-fibrotic compounds with regard to important PF parameters such as forced vital capacity [117]. Anti-oxidants may therefore play a key role in future PF treatment.

\section{Cross-Linking Prevents Proper Remodelling}

The role of enzymatic cross-links was earlier thought to be purely structural. Studies have, however, described other roles for these enzymes in the creation and maintenance of the pathologic microenvironment of cancer and fibrotic diseases [77]. One study showed that LOX and LOXL2 activity and expression correlate with the disorders observed in the microenvironment of tissues leading to cancer and fibrosis [77]. This is supported by other studies showing an increase in the number of cross-links per collagen molecule in fibrotic tissues [72]. It is speculated that this increase in cross-links contributes to the accumulation of collagens by reducing collagen digestibility $[3,118,119]$. LOXL2 levels have been mostly investigated in fibrotic lung tissues from patients with IPF [77], although LOX is often described as the main contributor to the increase in cross-linking in PF $[2,73]$. This is due to the higher LOXL expression in healthy tissues compared to LOXL2 [77].

Upregulation of LOXL2 mRNA as well as an increase in collagen cross-links has been associated with worsening of the lung tumour grade [77]. Therefore, a monoclonal antibody towards LOXL2 (AB0023) was developed which proved successful at inhibiting LOXL2 activity [77]. AB0023-treated mice in a primary tumour model experienced a significant decrease in the number of cross-linked collagens and a reduction in tumour volume compared to vehicle-treated mice. This not only links the ECM molecular environment to pathological states but also demonstrates the potential to exploit changes in the quality of the ECM to halt the progression of tumours. In this study, it was shown that the lung tissue of bleomycin-treated rats experienced a significant increase in LOXL2 and crosslinked collagens. The addition of AB0023 with bleomycin successfully reduced the amount of cross-linked collagen and fibrosis in lung tissue compared to the combination of vehicle and bleomycin. Besides preventing fibrosis, the addition of AB0023 after bleomycin injection showed that inhibition of LOXL2 could reverse established PF.

TG, especially TG2, is another type of enzymes capable of cross-linking ECM proteins into high molecular mass products with a high resistance against proteases $[78,80]$. Studies have shown that the quality - that is, the order/ distribution - of ECM proteins is also affected by the amount of TG, and that higher levels of this enzyme are detected during fibrosis [40]. TG is active at an earlier fibrosis stage than LOX $[39,40,81]$. As has been seen with LOX, inhibition of TG can also prevent ECM tissue remodelling [120].

These studies demonstrated how inhibition of an enzyme responsible for lung ECM quality could directly prevent and even reverse lung ECM remodelling and thus fibrosis. Other studies have also demonstrated that elastic fibres were present in the same quantity in lung ECM that was damaged and then repaired as compared to nondamaged lung ECM, but the distribution was still disordered after the repair process $[102,121]$.

\section{Protease-Derived ECM Fragments as Ameliorators}

To date, there are no approved efficacious therapies against fibrosis [122-124] but studies suggest that protease-derived ECM protein fragments may have potential therapeutic functions $[1,125]$. The C-terminus of collagen XVIII contains a $20-\mathrm{kDa}$ internal fragment named endostatin. Studies have determined the concentration of 


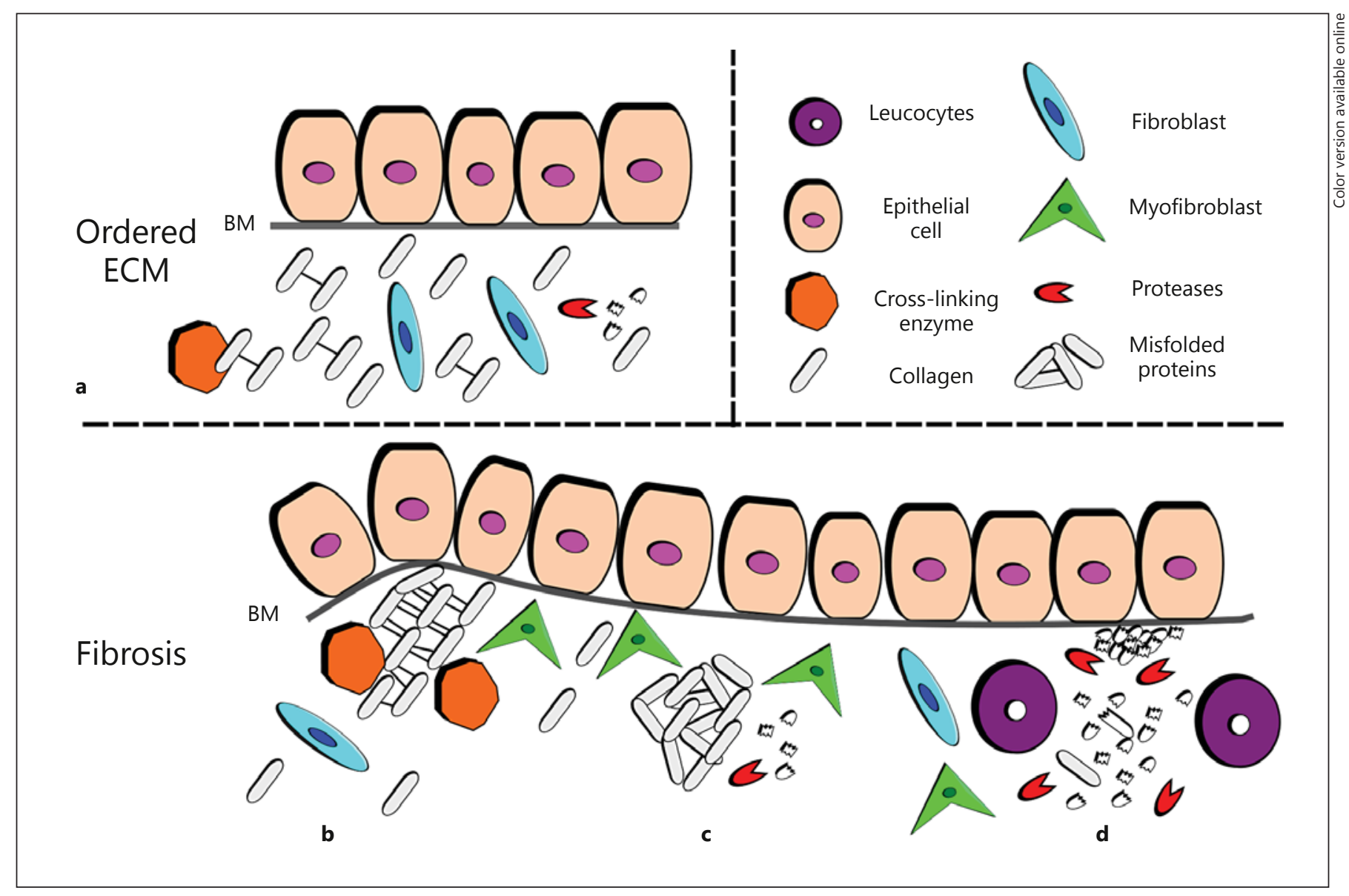

Fig. 1. PTMs alter the lung ECM quality. a In a controlled ECM environment, there is a fine proteostatic balance ensuring the high order/quality of the distribution of the ECM component and a moderate amount of PTMs. b-d In the progression of fibrosis, PTMs may also be responsible for the decreased order/quality of the ECM. b A local increase in cross-linking enzymes such as LOX or TG may induce an increase in cross-linked ECM proteins that cannot be degraded. c External influences together with PTMs such as citrullination may induce severe misfolding of proteins and disturb the proteostatic balance. If this occurs faster than the misfolded proteins are degraded, they will start to accumulate. Citrullination also render proteins more vulnerable to other PTMs such as proteolysis and cross-linking. $\mathbf{d}$ An increase in proteolytic cleavage of lung ECM proteins occurs in several pulmonary disorders including IPF. The protease-derived fragments are therefore often observed in the serum of IPF patients. The proteases observed in lung disorders are elastase-like serine proteases such as NE or metalloproteinases. $\mathrm{BM}=$ Basement membrane. endostatin in serum and/or bronchoalveolar lavage fluid from patients with IPF or systemic sclerosis-associated $\mathrm{PF}$ to be 2-20 times higher than in controls [125]. E4 is a fragment from the C-terminus of human endostatin with the addition of an amide modification at its C-terminus. Yamaguchi et al. [125] tested the anti-fibrotic properties of the endostatin-derived peptide $\mathrm{E} 4$ against $\mathrm{PF}$ ex vivo and in vivo. E4 was administrated either concomitantly or 3 days after bleomycin in rat lungs [125]. It was shown that $\mathrm{E} 4$ could not only prevent $\mathrm{PF}$ but also ameliorate it in vivo. This was demonstrated by immunohistochemistry and by a decreased concentration of collagen in the lung tissue. Furthermore, the secretion of LOX from normal adult human lung fibroblasts stimulated with TGF- $\beta$ and in mouse lung injected with bleomycin was examined. A reduction in LOX concentration upon the addition of E4 was observed in all cases.

The study also showed an association between the increase in collagen and LOX concentrations and PF [125]. The correlation between the quantity of collagen and the amount of a cross-linking enzyme could indicate that the cross-linking prevented proteases from degrading the collagen molecules. The quantity of ECM proteins was previously thought to be the main initiator of $\mathrm{PF}$ as an 
increase in collagen levels was observed in lung tissues from patients with PF $[103,126]$ despite an increase in lung protease concentrations [127].

Additional studies have shown that the progression of bleomycin-induced PF in rats is halted by the administration of pepsin-digested porcine urinary bladder matrix [6], whereas fibrosis could not be halted by the injection of non-digested porcine urinary bladder matrix. Such data indicates that two matrix materials that are microscopically the same, but not on a molecular level, result in two different outcomes in the pathogenesis of PF.

The E4 and porcine urinary bladder matrix studies illustrated how the lung ECM has not only structural functions but also an endocrine function, proving its active role in tissue remodelling. These endocrine properties may also produce negative outcomes. Elastin-derived peptides may induce anti-elastin autoimmunity in emphysema [66]. These fragments are able to stimulate an immune response in tissue where cytokines are upregulated, resulting in the upregulation of proteases leading to progressive destruction of the lung ECM. ECM-derived peptides may therefore not always possess therapeutic properties.

Figure 1 illustrates the consequences of changes in the lung ECM at the molecular level, which include crosslinking, proteolysis and citrullination of lung ECM proteins. All of these changes in lung ECM quality may reduce lung function. It is important to consider that many of these PTMs are essential for proper ECM protein distribution in the lung. It is mainly when the PTMs are overexpressed or absent that the quality is altered.

\section{Conclusion}

We have highlighted the key PTMs that are partly responsible for the progression of ECM remodelling in $\mathrm{PF}$. Previous literature has focused on the correlation of changes in ECM quantity with PF; however, the changes in ECM quantity have not been demonstrated as the main initiator of $\mathrm{PF}$, which may result from other processes.

Our speculation based on a review of the data is that PTMs of lung ECM proteins in coherence with quantity are part of some of the key processes responsible for the progression of PF. The PTMs most commonly affecting the quality of the ECM included proteolytic cleavage, oxidation and cross-linking. This has been proven by the example that removal of the source of cross-linking can ameliorate remodelled lung tissue. We reported evidence that the ECM has more than structural functions and is indeed a regulator of various tissue diseases. This has been proven as specific proteolytic cleavage of collagen or the entire matrix resulted in reduced fibrosis and even ameliorated lung ECM remodelling. This indicates that $\mathrm{PF}$ can be reversed once the ECM quality is restored.

\section{Future Perspectives}

As no current approved methods are able to diagnose severe pulmonary disorders before a certain level of severity is reached, it can be concluded that new markers for the early diagnosis of pulmonary diseases are needed. Recent data suggests that ECM quality is important in the progression of $\mathrm{PF}$. Biochemical marker targets that represent lung ECM quality may therefore aid in PF diagnosis and prognosis. The correlation between PF and quantitative changes is, however, evident. Therefore, markers or a single marker able to detect both qualitative and quantitative changes in the lung ECM are needed.

A key topic in modern medicine is customized treatment. State-of-the-art diagnostic and prognostic biochemical markers could help identify the treatment needed for individual patients. As mentioned, some total protein biomarkers may be upregulated during several diseases, which complicates the prescription of a single therapy. This may be significantly improved by measuring the protein fingerprints that are generated during a specific pathology. These are more specific markers than the total protein measurement and may offer a more disease-specific marker for diagnosis, prognosis and response to intervention. Some neo-epitopes may contain several PTMs, and biochemical markers targeting these would increase the specificity for diseases such as IPF.

\section{Acknowledgement}

We acknowledge the funding from the Danish Ministry of Science, Technology and Science and the Danish Science Foundation (Den Danske Forskningsfond).

References Karsdal MA, Nielsen MJ, Sand JM, Henriksen
K, Genovese F, Bay-Jensen AC, Victoria S,
Adamkewicz JI, Christiansen C, Leeming DJ:
Extracellular matrix remodeling: the com-
mon denominator in connective tissue dis-
eases possibilities for evaluation and current
understanding of the matrix as more than a
passive architecture, but a key player in tissue
failure. Assay Drug Dev Technol 2013;11:70-
92. 
-2 Counts DF, Evans JN, Dipetrillo TA, Sterling KM Jr, Kelley J: Collagen lysyl oxidase activity in the lung increases during bleomycin-induced lung fibrosis. J Pharmacol Exp Ther 1981;219:675-678.

-3 Mutsaers SE, Marshall RP, Goldsack NR, Laurent GJ, McAnulty RJ: Effect of endothelin receptor antagonists (BQ-485, Ro 47-0203) on collagen deposition during the development of bleomycin-induced pulmonary fibrosis in rats. Pulm Pharmacol Ther 1998;11:221-225.

4 Stone PJ, Gottlieb DJ, O'Connor GT, Ciccolella DE, Breuer R, Bryan-Rhadfi J, Shaw HA, Franzblau C, Snider GL: Elastin and collagen degradation products in urine of smokers with and without chronic obstructive pulmonary disease. Am J Respir Crit Care Med 1995;151:952-959.

5 Roman J: Extracellular matrix and lung inflammation. Immunol Res 1996;15:163-178.

-6 Manni ML, Czajka CA, Oury TD, Gilbert TW: Extracellular matrix powder protects against bleomycin-induced pulmonary fibrosis. Tissue Eng Part A 2011;17:2795-2804.

-7 Adair-Kirk TL, Senior RM: Fragments of extracellular matrix as mediators of inflammation. Int J Biochem Cell Biol 2008;40:1101-1110.

-8 Ohnishi K, Takagi M, Kurokawa Y, Satomi S, Konttinen YT: Matrix metalloproteinase-mediated extracellular matrix protein degradation in human pulmonary emphysema. Lab Invest 1998;78:1077-1087.

-9 Aumailley M, Gayraud B: Structure and biological activity of the extracellular matrix. J Mol Med (Berl) 1998;76:253-265.

10 Barroso B, Abello N, Bischoff R: Study of human lung elastin degradation by different elastases using high-performance liquid chromatography/mass spectrometry. Anal Biochem 2006;358:216-224

11 Luisetti M, Ma S, Iadarola P, Stone PJ, Viglio S, Casado B, Lin YY, Snider GL, Turino GM Desmosine as a biomarker of elastin degradation in COPD: current status and future directions. Eur Respir J 2008;32:1146-1157.

12 Turino GM, Keller S, Chrzanowski P, Osman M, Cerreta J, Mandl I: Lung elastin content in normal and emphysematous lungs. Bull Eur Physiopathol Respir 1980;16:43-57.

13 Chrzanowski P, Keller S, Cerreta J, Mandl I, Turino GM: Elastin content of normal and emphysematous lung parenchyma. Am J Med 1980;69:351-359.

14 Bradley K, Connell-Breul S, Crystal RG: Collagen in the human lung: quantitation of rates of synthesis and partial characterization of composition. J Clin Invest 1975;55:543-550.

15 Vancheri C, Failla M, Crimi N, Raghu G: Idiopathic pulmonary fibrosis: a disease with similarities and links to cancer biology. Eur Respir J 2010;35:496-504.

16 American Thoracic Society: Idiopathic pulmonary fibrosis: diagnosis and treatment. International consensus statement. American Thoracic Society (ATS), and the European Respiratory Society (ERS). Am J Respir Crit Care Med 2000;161:646-664.
17 American Thoracic Society, European Respiratory Society: American Thoracic Society/ European Respiratory Society International Multidisciplinary Consensus Classification of the Idiopathic Interstitial Pneumonias. This joint statement of the American Thoracic Society (ATS), and the European Respiratory Society (ERS) was adopted by the ATS board of directors, June 2001 and by the ERS Executive Committee, June 2001. Am J Respir Crit Care Med 2002;165:277-304.

18 King TE Jr, Pardo A, Selman M: Idiopathic pulmonary fibrosis. Lancet 2011;378:1949-1961.

19 Willis BC, Borok Z: TGF-beta-induced EMT: mechanisms and implications for fibrotic lung disease. Am J Physiol Lung Cell Mol Physiol 2007;293:L525-L534.

20 Tatler AL, Jenkins G: TGF-beta activation and lung fibrosis. Proc Am Thorac Soc 2012; 9:130-136.

21 Ponticos M, Holmes AM, Shi-Wen X, Leoni P, Khan K, Rajkumar VS, Hoyles RK, BouGharios G, Black CM, Denton CP, Abraham DJ, Leask A, Lindahl GE: Pivotal role of connective tissue growth factor in lung fibrosis: MAPK-dependent transcriptional activation of type I collagen. Arthritis Rheum 2009;60: 2142-2155.

22 Ventetuolo CE, Kawut SM, Lederer DJ: Plasma endothelin-1 and vascular endothelial growth factor levels and their relationship to hemodynamics in idiopathic pulmonary fibrosis. Respiration 2012;84:299-305.

23 Distler JH, Schett G, Gay S, Distler O: The controversial role of tumor necrosis factor alpha in fibrotic diseases. Arthritis Rheum 2008;58:2228-2235.

24 Lo RS, Lecocq M, Uwambayinema F, Yakoub Y, Delos M, Demoulin JB, Lucas S, Sparwasser T, Renauld JC, Lison D, Huaux F: Platelet-derived growth factor-producing CD4+ Foxp3+ regulatory $\mathrm{T}$ lymphocytes promote lung fibrosis. Am J Respir Crit Care Med 2011;184: 1270-1281.

25 Konigshoff M, Balsara N, Pfaff EM, Kramer M, Chrobak I, Seeger W, Eickelberg O: Functional Wnt signaling is increased in idiopathic pulmonary fibrosis. PLoS One 2008;3: e2142.

26 Clause KC, Barker TH: Extracellular matrix signaling in morphogenesis and repair. Curr Opin Biotechnol 2013;24:830-833.

27 Daley WP, Yamada KM: ECM-modulated cellular dynamics as a driving force for tissue morphogenesis. Curr Opin Genet Dev 2013; 23:408-414

28 Kruegel J, Miosge N: Basement membrane components are key players in specialized extracellular matrices. Cell Mol Life Sci 2010;67: 2879-2895.

29 Cloos PA, Christgau S: Post-translational modifications of proteins: implications for aging, antigen recognition, and autoimmunity. Biogerontology 2004;5:139-158.

30 Leeming DJ, Bay-Jensen AC, Vassiliadis E, Larsen MR, Henriksen K, Karsdal MA: Posttranslational modifications of the extracellu- lar matrix are key events in cancer progression: opportunities for biochemical marker development. Biomarkers 2011;16:193-205.

- 31 Karsdal MA, Henriksen K, Leeming DJ, Woodworth T, Vassiliadis E, Bay-Jensen AC: Novel combinations of post-translational modification (PTM) neo-epitopes provide tissue-specific biochemical markers - are they the cause or the consequence of the disease? Clin Biochem 2010;43:793-804.

- 32 Barascuk N, Vassiliadis E, Larsen L, Wang J, Zheng Q, Xing R, Cao Y, Crespo C, Lapret I, Sabatini M, Villeneuve N, Vilaine JP, Rasmussen LM, Register TC, Karsdal MA: Development and validation of an enzyme-linked immunosorbent assay for the quantification of a specific MMP-9 mediated degradation fragment of type III collagen - a novel biomarker of atherosclerotic plaque remodeling. Clin Biochem 2011;44:900-906.

33 Leeming DJ, Sand JM, Nielsen MJ, Genovese F, Martinez FJ, Hogaboam CM, Han MK, Klickstein LB, Karsdal MA: Serological investigation of the collagen degradation profile of patients with chronic obstructive pulmonary disease or idiopathic pulmonary fibrosis. Biomark Insights 2012;7:119-126.

-34 Skjot-Arkil H, Clausen RE, Nguyen QH, Wang Y, Zheng Q, Martinez FJ, Hogaboam CM, Han M, Klickstein LB, Larsen MR, Nawrocki A, Leeming DJ, Karsdal MA: Measurement of MMP-9 and -12 degraded elastin (ELM) provides unique information on lung tissue degradation. BMC Pulm Med 2012;12:34

35 Veidal SS, Karsdal MA, Nawrocki A, Larsen MR, Dai Y, Zheng Q, Hagglund P, Vainer B, Skjot-Arkil H, Leeming DJ: Assessment of proteolytic degradation of the basement membrane: a fragment of type IV collagen as a biochemical marker for liver fibrosis. Fibrogenesis Tissue Repair 2011;4:22.

36 Belvisi MG, Bottomley KM: The role of matrix metalloproteinases (MMPs) in the pathophysiology of chronic obstructive pulmonary disease (COPD): a therapeutic role for inhibitors of MMPs? Inflamm Res 2003;52:95-100.

37 Myllyharju J, Kivirikko KI: Collagens, modifying enzymes and their mutations in humans, flies and worms. Trends Genet 2004;20: 33-43.

38 Iismaa SE, Mearns BM, Lorand L, Graham RM: Transglutaminases and disease: lessons from genetically engineered mouse models and inherited disorders. Physiol Rev 2009;89: 991-1023.

- 39 Olsen KC, Sapinoro RE, Kottmann RM, Kulkarni AA, Iismaa SE, Johnson GV, Thatcher TH, Phipps RP, Sime PJ: Transglutaminase 2 and its role in pulmonary fibrosis. Am J Respir Crit Care Med 2011;184:699707.

40 Grenard P, Bresson-Hadni S, El Alaoui S, Chevallier M, Vuitton DA, Ricard-Blum S: Transglutaminase-mediated cross-linking is involved in the stabilization of extracellular matrix in human liver fibrosis. J Hepatol 2001;35:367-375. 
41 Vrhovski B, Weiss AS: Biochemistry of tropoelastin. Eur J Biochem 1998;258:1-18.

42 Starcher BC: Elastin and the lung. Thorax 1986;41:577-585.

43 Csiszar K: Lysyl oxidases: a novel multifunctional amine oxidase family. Prog Nucleic Acid Res Mol Biol 2001;70:1-32.

-44 Heinz A, Taddese S, Sippl W, Neubert RH, Schmelzer CE: Insights into the degradation of human elastin by matrilysin-1. Biochimie 2011;93:187-194.

45 Wilson CL, Matrisian LM: Matrilysin: an epithelial matrix metalloproteinase with potentially novel functions. Int J Biochem Cell Biol 1996;28:123-136.

-46 Russell RE, Thorley A, Culpitt SV, Dodd S, Donnelly LE, Demattos C, Fitzgerald M, Barnes PJ: Alveolar macrophage-mediated elastolysis: roles of matrix metalloproteinases, cysteine, and serine proteases. Am J Physiol Lung Cell Mol Physiol 2002;283:L867-L873.

47 Shapiro SD: Proteinases in chronic obstructive pulmonary disease. Biochem Soc Trans 2002;30:98-102.

48 Kielty CM, Sherratt MJ, Shuttleworth CA: Elastic fibres. J Cell Sci 2002;115:2817-2828.

-49 Li Y, Jiang D, Liang J, Meltzer EB, Gray A, Miura R, Wogensen L, Yamaguchi Y, Noble PW: Severe lung fibrosis requires an invasive fibroblast phenotype regulated by hyaluronan and CD44. J Exp Med 2011;208:1459-1471.

50 Margadant C, Sonnenberg A: Integrin-TGFbeta crosstalk in fibrosis, cancer and wound healing. EMBO Rep 2010;11:97-105.

-51 Eisenhaber B, Eisenhaber F: Posttranslational modifications and subcellular localization signals: indicators of sequence regions without inherent 3D structure? Curr Protein Pept Sci 2007;8:197-203.

-52 Eisenhaber F, Eisenhaber B, Kubina W, Maurer-Stroh S, Neuberger G, Schneider G, Wildpaner M: Prediction of lipid posttranslational modifications and localization signals from protein sequences: big-Pi, NMT and PTS1. Nucleic Acids Res 2003;31:3631-3634.

\53 Karsdal MA, Henriksen K, Leeming DJ, Mitchell P, Duffin K, Barascuk N, Klickstein L, Aggarwal P, Nemirovskiy O, Byrjalsen I, Qvist P, Bay-Jensen AC, Dam EB, Madsen $\mathrm{SH}$, Christiansen C: Biochemical markers and the FDA critical path: how biomarkers may contribute to the understanding of pathophysiology and provide unique and necessary tools for drug development. Biomarkers 2009; 14:181-202.

54 Bennett CM, Guo M, Dharmage SC: HbA(1c) as a screening tool for detection of type 2 diabetes: a systematic review. Diabet Med 2007; 24:333-343.

55 Gillett MJ: International Expert Committee report on the role of the Alc assay in the diagnosis of diabetes: Diabetes Care 2009;32: 1327-1334. Clin Biochem Rev 2009;30:197200.
56 Lamblin G, Degroote S, Perini JM, Delmotte P, Scharfman A, Davril M, Lo-Guidice JM, Houdret N, Dumur V, Klein A, Rousse P: Human airway mucin glycosylation: a combinatory of carbohydrate determinants which vary in cystic fibrosis. Glycoconj J 2001;18:661684.

57 Davril M, Degroote S, Humbert P, Galabert C, Dumur V, Lafitte JJ, Lamblin G, Roussel P: The sialylation of bronchial mucins secreted by patients suffering from cystic fibrosis or from chronic bronchitis is related to the severity of airway infection. Glycobiology 1999; 9:311-321.

58 Segura-Valdez L, Pardo A, Gaxiola M, Uhal $\mathrm{BD}$, Becerril C, Selman M: Upregulation of gelatinases $\mathrm{A}$ and $\mathrm{B}$, collagenases 1 and 2 , and increased parenchymal cell death in COPD. Chest 2000;117:684-694.

59 Russell RE, Culpitt SV, DeMatos C, Donnelly L, Smith M, Wiggins J, Barnes PJ: Release and activity of matrix metalloproteinase- 9 and tissue inhibitor of metalloproteinase- 1 by alveolar macrophages from patients with chronic obstructive pulmonary disease. Am J Respir Cell Mol Biol 2002;26:602-609.

60 Maclay JD, McAllister DA, Rabinovich R, Haq I, Maxwell S, Hartland S, Connell M, Murchison JT, van Beek EJ, Gray RD, Mills NL, Macnee W: Systemic elastin degradation in chronic obstructive pulmonary disease. Thorax 2012;67:606-612.

-61 Finlay GA, O’Driscoll LR, Russell KJ, D’Arcy EM, Masterson JB, Fitzgerald MX, O'Connor CM: Matrix metalloproteinase expression and production by alveolar macrophages in emphysema. Am J Respir Crit Care Med 1997; 156:240-247.

62 Ishii H, Mukae H, Kadota J, Kaida H, Nagata T, Abe K, Matsukura S, Kohno S: High serum concentrations of surfactant protein A in usual interstitial pneumonia compared with nonspecific interstitial pneumonia. Thorax 2003; 58:52-57.

63 Janoff A, Sloan B, Weinbaum G, Damiano V, Sandhaus RA, Elias J, Kimbel P: Experimental emphysema induced with purified human neutrophil elastase: tissue localization of the instilled protease. Am Rev Respir Dis 1977; 115:461-478.

64 Abboud RT, Vimalanathan S: Pathogenesis of COPD. 1. The role of protease-antiprotease imbalance in emphysema. Int $\mathrm{J}$ Tuberc Lung Dis 2008; 12:361-367.

-65 Maquart FX, Pasco S, Ramont L, Hornebeck W, Monboisse JC: An introduction to matrikines: extracellular matrix-derived peptides which regulate cell activity - implication in tumor invasion. Crit Rev Oncol Hematol 2004;49:199-202.

66 Lee SH, Goswami S, Grudo A, Song LZ, Bandi V, Goodnight-White S, Green L, HackenBitar J, Huh J, Bakaeen F, Coxson HO, Cogswell S, Storness-Bliss C, Corry DB, Kheradmand F: Antielastin autoimmunity in tobacco smoking-induced emphysema. Nat Med 2007; 13:567-569.
67 Elbjeirami WM, Yonter EO, Starcher BC, West JL: Enhancing mechanical properties of tissue-engineered constructs via lysyl oxidase crosslinking activity. J Biomed Mater Res A 2003;66:513-521.

68 Barker HE, Erler JT: The potential for LOXL2 as a target for future cancer treatment. Future Oncol 2011;7:707-710.

69 Paszek MJ, Zahir N, Johnson KR, Lakins JN, Rozenberg GI, Gefen A, Reinhart-King CA, Margulies SS, Dembo M, Boettiger D, Hammer DA, Weaver VM: Tensional homeostasis and the malignant phenotype. Cancer Cell 2005;8:241-254.

70 Bignon M, Pichol-Thievend C, Hardouin J, Malbouyres M, Brechot N, Nasciutti L, Barret A, Teillon J, Guillon E, Etienne E, Caron M, Joubert-Caron R, Monnot C, Ruggiero F, Muller L, Germain S: Lysyl oxidase-like protein-2 regulates sprouting angiogenesis and type IV collagen assembly in the endothelial basement membrane. Blood 2011;118:39793989.

71 Cronlund AL, Smith BD, Kagan HM: Binding of lysyl oxidase to fibrils of type I collagen. Connect Tissue Res 1985;14:109-119.

72 Brinckmann J, Neess CM, Gaber Y, Sobhi H, Notbohm H, Hunzelmann N, Fietzek PP, Muller PK, Risteli J, Gebker R, ScharffetterKochanek K: Different pattern of collagen cross-links in two sclerotic skin diseases: lipodermatosclerosis and circumscribed scleroderma. J Invest Dermatol 2001;117: 269-273.

73 Tzortzaki EG, Tischfield JA, Sahota A, Siafakas NM, Gordon MK, Gerecke DR: Expression of FACIT collagens XII and XIV during bleomycin-induced pulmonary fibrosis in mice. Anat Rec A Discov Mol Cell Evol Biol 2003;275:1073-1080.

74 Romero-Chapman N, Lee J, Tinker D, UriuHare JY, Keen CL, Rucker RR: Purification, properties and influence of dietary copper on accumulation and functional activity of lysyl oxidase in rat skin. Biochem J 1991;275:657662.

75 Rucker RB, Romero-Chapman N, Wong T, Lee J, Steinberg FM, McGee C, Clegg MS, Reiser K, Kosonen T, Uriu-Hare JY, Murphy J, Keen CL: Modulation of lysyl oxidase by dietary copper in rats. J Nutr 1996;126:5160.

76 Kothapalli CR, Ramamurthi A: Lysyl oxidase enhances elastin synthesis and matrix formation by vascular smooth muscle cells. J Tissue Eng Regen Med 2009;3:655-661.

-77 Barry-Hamilton V, Spangler R, Marshall D, McCauley S, Rodriguez HM, Oyasu M, Mikels A, Vaysberg M, Ghermazien H, Wai C, Garcia CA, Velayo AC, Jorgensen B, Biermann D, Tsai D, Green J, Zaffryar-Eilot S, Holzer A, Ogg S, Thai D, Neufeld G, Van Vlasselaer P, Smith V: Allosteric inhibition of lysyl oxidase-like-2 impedes the development of a pathologic microenvironment. Nat Med 2010;16:1009-1017. 
78 Griffin M, Casadio R, Bergamini CM: Transglutaminases: nature's biological glues. Biochem J 2002;368:377-396.

-79 Lorand L, Graham RM: Transglutaminases: crosslinking enzymes with pleiotropic functions. Nat Rev Mol Cell Biol 2003;4:140-156.

-80 Schittny JC, Paulsson M, Vallan C, Burri PH, Kedei N, Aeschlimann D: Protein cross-linking mediated by tissue transglutaminase correlates with the maturation of extracellular matrices during lung development. Am J Respir Cell Mol Biol 1997;17:334-343.

81 Griffin M, Smith LL, Wynne J: Changes in transglutaminase activity in an experimental model of pulmonary fibrosis induced by paraquat. Br J Exp Pathol 1979;60:653-661.

\$2 Daniil ZD, Papageorgiou E, Koutsokera A, Kostikas K, Kiropoulos T, Papaioannou AI, Gourgoulianis KI: Serum levels of oxidative stress as a marker of disease severity in idiopathic pulmonary fibrosis. Pulm Pharmacol Ther 2008;21:26-31.

83 Hecker L, Vittal R, Jones T, Jagirdar R, Luckhardt TR, Horowitz JC, Pennathur S, Martinez FJ, Thannickal VJ: NADPH oxidase-4 mediates myofibroblast activation and fibrogenic responses to lung injury. Nat Med 2009; 15:1077-1081.

84 Lenz AG, Costabel U, Maier KL: Oxidized BAL fluid proteins in patients with interstitial lung diseases. Eur Respir J 1996;9:307-312.

-85 Markart P, Luboeinski T, Korfei M, Schmidt R, Wygrecka M, Mahavadi P, Mayer K, Wilhelm J, Seeger W, Guenther A, Ruppert C: Alveolar oxidative stress is associated with elevated levels of nonenzymatic low-molecular-weight antioxidants in patients with different forms of chronic fibrosing interstitial lung diseases. Antioxid Redox Signal 2009;11:227-240.

-86 Kinnula VL, Hodgson UA, Lakari EK, Tan RJ, Sormunen RT, Soini YM, Kakko SJ, Laitinen TH, Oury TD, Paakko PK: Extracellular superoxide dismutase has a highly specific localization in idiopathic pulmonary fibrosis/ usual interstitial pneumonia. Histopathology 2006;49:66-74.

-87 Tan RJ, Fattman CL, Niehouse LM, Tobolewski JM, Hanford LE, Li Q, Monzon FA, Parks WC, Oury TD: Matrix metalloproteinases promote inflammation and fibrosis in asbestos-induced lung injury in mice. Am J Respir Cell Mol Biol 2006;35:289-297.

-88 Anathy V, Roberson E, Cunniff B, Nolin JD, Hoffman S, Spiess P, Guala AS, Lahue KG, Goldman D, Flemer S, van der Vliet A, Heintz $\mathrm{NH}$, Budd RC, Tew KD, Janssen-Heininger YM: Oxidative processing of latent Fas in the endoplasmic reticulum controls the strength of apoptosis. Mol Cell Biol 2012;32:34643478.

-89 Baka Z, Gyorgy B, Geher P, Buzas EI, Falus A, Nagy G: Citrullination under physiological and pathological conditions. Joint Bone Spine 2012;79:431-436.
90 Gyorgy B, Toth E, Tarcsa E, Falus A, Buzas EI: Citrullination: a posttranslational modification in health and disease. Int J Biochem Cell Biol 2006;38:1662-1677.

-91 Vossenaar ER, Zendman AJ, van Venrooij WJ, Pruijn GJ: PAD, a growing family of citrullinating enzymes: genes, features and involvement in disease. Bioessays 2003;25: 1106-1118.

92 Asaga H, Yamada M, Senshu T: Selective deimination of vimentin in calcium ionophore-induced apoptosis of mouse peritoneal macrophages. Biochem Biophys Res Commun 1998;243:641-646.

-93 Tarcsa E, Marekov LN, Mei G, Melino G, Lee SC, Steinert PM: Protein unfolding by peptidylarginine deiminase: substrate specificity and structural relationships of the natural substrates trichohyalin and filaggrin. J Biol Chem 1996;271:30709-30716.

-94 Tarcsa E, Marekov LN, Andreoli J, Idler WW, Candi E, Chung SI, Steinert PM: The fate of trichohyalin: sequential post-translational modifications by peptidyl-arginine deiminase and transglutaminases. J Biol Chem 1997;272:27893-27901.

-95 Vassiliadis E, Oliveira CP, Alvares-da-Silva MR, Zhang C, Carrilho FJ, Stefano JT, Rabelo F, Pereira L, Kappel CR, Henriksen K, Veidal SS, Vainer B, Duffin KL, Christiansen C, Leeming DJ, Karsdal M: Circulating levels of citrullinated and MMP-degraded vimentin (VICM) in liver fibrosis related pathology. Am J Transl Res 2012;4:403-414.

-96 Bouchecareilh M, Balch WE: Proteostasis: a new therapeutic paradigm for pulmonary disease. Proc Am Thorac Soc 2011;8:189195.

-97 Balch WE, Morimoto RI, Dillin A, Kelly JW: Adapting proteostasis for disease intervention. Science 2008;319:916-919.

-98 Balch WE, Sznajder JI, Budinger S, Finley D, Laposky AD, Cuervo AM, Benjamin IJ, Barreiro E, Morimoto RI, Postow L, Weissman AM, Gail D, Banks-Schlegel S, Croxton T, Gan W: Malfolded protein structure and proteostasis in lung diseases. Am J Respir Crit Care Med 2014;189:96-103.

-99 Karsdal MA, Byrjalsen I, Bay-Jensen AC, Henriksen K, Riis BJ, Christiansen C: Biochemical markers identify influences on bone and cartilage degradation in osteoarthritis - the effect of sex, Kellgren-Lawrence (KL) score, body mass index (BMI), oral salmon calcitonin (sCT) treatment and diurnal variation. BMC Musculoskelet Disord 2010;11:125.

100 Byrjalsen I, Leeming DJ, Qvist P, Christiansen C, Karsdal MA: Bone turnover and bone collagen maturation in osteoporosis: effects of antiresorptive therapies. Osteoporos Int 2008; 19:339-348.
101 Leeming DJ, Delling G, Koizumi M, Henriksen K, Karsdal MA, Li B, Qvist P, Tanko LB, Byrjalsen I: Alpha CTX as a biomarker of skeletal invasion of breast cancer: immunolocalization and the load dependency of urinary excretion. Cancer Epidemiol Biomarkers Prev 2006;15:1392-1395.

102 Rucker RB, Dubick MA: Elastin metabolism and chemistry: potential roles in lung development and structure. Environ Health Perspect 1984;55:179-191.

103 Selman M, Ruiz V, Cabrera S, Segura L, Ramirez R, Barrios R, Pardo A: TIMP-1, -2, -3 , and -4 in idiopathic pulmonary fibrosis: a prevailing nondegradative lung microenvironment? Am J Physiol Lung Cell Mol Physiol 2000;279:L562-L574.

104 Salazar LM, Herrera AM: Fibrotic response of tissue remodeling in COPD. Lung 2011; 189:101-109.

105 Macnee W, Wiggs B, Belzberg AS, Hogg JC: The effect of cigarette smoking on neutrophil kinetics in human lungs. N Engl J Med 1989;321:924-928.

106 Hogg JC: Why does airway inflammation persist after the smoking stops? Thorax 2006;61:96-97.

107 Stupack DG, Cheresh DA: ECM remodeling regulates angiogenesis: endothelial integrins look for new ligands. Sci STKE 2002; 2002:e7.

108 Hanumegowda C, Farkas L, Kolb M: Angiogenesis in pulmonary fibrosis: too much or not enough? Chest 2012;142:200-207.

109 Zioupos P, Currey JD, Hamer AJ: The role of collagen in the declining mechanical properties of aging human cortical bone. J Biomed Mater Res 1999;45:108-116.

110 Zimmermann EA, Schaible E, Bale H, Barth HD, Tang SY, Reichert P, Busse B, Alliston T, Ager JW 3rd, Ritchie RO: Age-related changes in the plasticity and toughness of human cortical bone at multiple length scales. Proc Natl Acad Sci USA 2011;108: 14416-14421.

111 Wang X, Shen X, Li X, Agrawal CM: Agerelated changes in the collagen network and toughness of bone. Bone 2002;31:1-7.

112 Roodman GD: Mechanisms of bone metastasis. Discov Med 2004;4:144-148.

113 Murthy S, Adamcakova-Dodd A, Perry SS, Tephly LA, Keller RM, Metwali N, Meyerholz DK, Wang Y, Glogauer M, Thorne PS, Carter AB: Modulation of reactive oxygen species by Racl or catalase prevents asbestos-induced pulmonary fibrosis. Am J Physiol Lung Cell Mol Physiol 2009; 297:L846-L855.

114 Cuzzocrea S, Genovese T, Failla M, Vecchio G, Fruciano M, Mazzon E, Di Paola R, Muia C, La Rosa C, Crimi N, Rizzarelli E, Vancheri C: Protective effect of orally administered carnosine on bleomycin-induced lung injury. Am J Physiol Lung Cell Mol Physiol 2007; 292:L1095-L1104. 
-115 Borok Z, Buhl R, Grimes GJ, Bokser AD, Hubbard RC, Holroyd KJ, Roum JH, Czerski DB, Cantin AM, Crystal RG: Effect of glutathione aerosol on oxidant-antioxidant imbalance in idiopathic pulmonary fibrosis. Lancet 1991;338:215-216.

116 Mitani Y, Sato K, Muramoto Y, Karakawa T, Kitamado M, Iwanaga $T$, Nabeshima $T$, Maruyama K, Nakagawa K, Ishida K, Sasamoto K: Superoxide scavenging activity of pirfenidone-iron complex. Biochem Biophys Res Commun 2008;372:19-23.

117 Behr J, Demedts M, Buhl R, Costabel U, Dekhuijzen RP, Jansen HM, Macnee W, Thomeer M, Wallaert B, Laurent F, Nicholson AG, Verbeken EK, Verschakelen J, Flower CD, Petruzzelli S, De Vuyst P, van den Bosch JM, Rodriguez-Becerra E, Lankhorst I, Sardina M, Boissard G: Lung function in idiopathic pulmonary fibrosis - extended analyses of the IFIGENIA trial. Respir Res 2009;10:101.

118 Wang Q, Wang Y, Hyde DM, Gotwals PJ, Koteliansky VE, Ryan ST, Giri SN: Reduction of bleomycin induced lung fibrosis by transforming growth factor beta soluble receptor in hamsters. Thorax 1999;54:805812.

-119 Borkham-Kamphorst E, Stoll D, Gressner AM, Weiskirchen R: Antisense strategy against PDGF B-chain proves effective in preventing experimental liver fibrogenesis. Biochem Biophys Res Commun 2004;321: 413-423.

-120 Johnson TS, Fisher M, Haylor JL, Hau Z, Skill NJ, Jones R, Saint R, Coutts I, Vickers ME, El Nahas AM, Griffin M: Transglutaminase inhibition reduces fibrosis and preserves function in experimental chronic kidney disease. J Am Soc Nephrol 2007;18: 3078-3088.

121 Shifren A, Mecham RP: The stumbling block in lung repair of emphysema: elastic fiber assembly. Proc Am Thorac Soc 2006;3:428433.

122 Bjoraker JA, Ryu JH, Edwin MK, Myers JL, Tazelaar HD, Schroeder DR, Offord KP: Prognostic significance of histopathologic subsets in idiopathic pulmonary fibrosis. Am J Respir Crit Care Med 1998;157:199203.

123 Varga J, Abraham D: Systemic sclerosis: a prototypic multisystem fibrotic disorder. J Clin Invest 2007;117:557-567.

124 Wynn TA: Common and unique mechanisms regulate fibrosis in various fibroproliferative diseases. J Clin Invest 2007;117: 524-529.

125 Yamaguchi Y, Takihara T, Chambers RA, Veraldi KL, Larregina AT, Feghali-Bostwick CA: A peptide derived from endostatin ameliorates organ fibrosis. Sci Transl Med 2012; 4:136ra71.
126 Last JA, Siefkin AD, Reiser KM: Type I collagen content is increased in lungs of patients with adult respiratory distress syndrome. Thorax 1983;38:364-368.

127 Rosas IO, Richards TJ, Konishi K, Zhang Y, Gibson K, Lokshin AE, Lindell KO, Cisneros J, Macdonald SD, Pardo A, Sciurba F, Dauber J, Selman M, Gochuico BR, Kaminski N: MMP1 and MMP7 as potential peripheral blood biomarkers in idiopathic pulmonary fibrosis. PLoS Med 2008;5:e93.

128 Pelosi P, Rocco PR, Negrini D, Passi A: The extracellular matrix of the lung and its role in edema formation. An Acad Bras Cienc 2007;79:285-297.

129 Carp H, Miller F, Hoidal JR, Janoff A: Potential mechanism of emphysema: alpha 1-proteinase inhibitor recovered from lungs of cigarette smokers contains oxidized methionine and has decreased elastase inhibitory capacity. Proc Natl Acad Sci USA 1982;79: 2041-2045.

130 Gyorgy B, Modos K, Pallinger E, Paloczi K, Pasztoi M, Misjak P, Deli MA, Sipos A, Szalai A, Voszka I, Polgar A, Toth K, Csete M, Nagy G, Gay S, Falus A, Kittel A, Buzas EI: Detection and isolation of cell-derived microparticles are compromised by protein complexes resulting from shared biophysical parameters. Blood 2011;117:e39-e48.

131 Lamblin G, Lhermitte M, Boersma A, Roussel P, Reinhold V: Oligosaccharides of human bronchial glycoproteins. Neutral diand trisaccharides isolated from a patient suffering from chronic bronchitis. J Biol Chem 1980;255:4595-4598.

132 Lhermitte M, Rahmoune H, Lamblin G, Roussel P, Strang AM, van Halbeek H: Structures of neutral oligosaccharides isolated from the respiratory mucins of a nonsecretor $(\mathrm{O}, \mathrm{Le}(\mathrm{a}+\mathrm{b}-))$ patient suffering from chronic bronchitis. Glycobiology 1991; 1:277-293.

133 Vuorinen K, Myllarniemi M, Lammi L, Piirila P, Rytila P, Salmenkivi K, Kinnula VL: Elevated matrilysin levels in bronchoalveolar lavage fluid do not distinguish idiopathic pulmonary fibrosis from other interstitial lung diseases. APMIS 2007;115:969-975.

134 Leeming D, He Y, Veidal S, Nguyen Q, Larsen D, Koizumi M, Segovia-Silvestre T, Zhang C, Zheng Q, Sun S, Cao Y, Barkholt V, Hagglund P, Bay-Jensen A, Qvist P, Karsdal M: A novel marker for assessment of liver matrix remodeling: an enzyme-linked immunosorbent assay (ELISA) detecting a MMP generated type I collagen neo-epitope (C1M). Biomarkers 2011;16:616-628.

135 Barascuk N, Veidal SS, Larsen L, Larsen DV, Larsen MR, Wang J, Zheng Q, Xing R, Cao Y, Rasmussen LM, Karsdal MA: A novel assay for extracellular matrix remodeling associated with liver fibrosis: an enzymelinked immunosorbent assay (ELISA) for a MMP-9 proteolytically revealed neo-epitope of type III collagen. Clin Biochem 2010; 43:899-904.
36 Veidal SS, Larsen DV, Chen X, Sun S, Zheng Q, Bay-Jensen AC, Leeming DJ, Nawrocki A, Larsen MR, Schett G, Karsdal MA: MMP mediated type $\mathrm{V}$ collagen degradation (C5M) is elevated in ankylosing spondylitis. Clin Biochem 2012;45:541-546.

137 Veidal SS, Karsdal MA, Vassiliadis E, Nawrocki A, Larsen MR, Nguyen QH, Hagglund P, Luo Y, Zheng Q, Vainer B, Leeming DJ: MMP mediated degradation of type VI collagen is highly associated with liver fibrosis - identification and validation of a novel biochemical marker assay. PLoS One 2011; 6:e24753.

138 Veidal SS, Vassiliadis E, Bay-Jensen AC, Tougas G, Vainer B, Karsdal MA: Procollagen type I N-terminal propeptide (PINP) is a marker for fibrogenesis in bile duct ligation-induced fibrosis in rats. Fibrogenesis Tissue Repair 2010;3:5.

139 Leeming DJ, Nielsen MJ, Dai Y, Veidal SS, Vassiliadis E, Zhang C, He Y, Vainer B, Zheng Q, Karsdal MA: Enzyme-linked immunosorbent serum assay specific for the $7 \mathrm{~S}$ domain of collagen type IV (P4NP 7S): a marker related to the extracellular matrix remodeling during liver fibrogenesis. Hepatol Res 2012;42:482-493.

140 Vassiliadis E, Veidal SS, Simonsen H, Larsen DV, Vainer B, Chen X, Zheng Q, Karsdal MA, Leeming DJ: Immunological detection of the type $\mathrm{V}$ collagen propeptide fragment, PVCP-1230, in connective tissue remodeling associated with liver fibrosis. Biomarkers 2011;16:426-433.

141 Trocme C, Leroy V, Sturm N, Hilleret MN, Bottari S, Morel F, Zarski JP: Longitudinal evaluation of a fibrosis index combining MMP-1 and PIIINP compared with MMP9, TIMP-1 and hyaluronic acid in patients with chronic hepatitis $C$ treated by interferon-alpha and ribavirin. J Viral Hepat 2006; 13:643-651.

142 Skjot-Arkil H, Barascuk N, Register T, Karsdal MA: Macrophage-mediated proteolytic remodeling of the extracellular matrix in atherosclerosis results in neoepitopes: a potential new class of biochemical markers. Assay Drug Dev Technol 2010;8:542-552.

143 Genovese F, Barascuk N, Larsen L, Larsen MR, Nawrocki A, Li Y, Zheng Q, Wang J, Veidal SS, Leeming DJ, Karsdal MA: Biglycan fragmentation in pathologies associated with extracellular matrix remodeling by matrix metalloproteinases. Fibrogenesis Tissue Repair 2013;6:9.

144 Wagner E, Skoumal M, Bayer PM, Klaushofer K: Antibody against mutated citrullinated vimentin: a new sensitive marker in the diagnosis of rheumatoid arthritis. Rheumatol Int 2009;29:1315-1321. 